\title{
Amalgamation of Terrestrial Heat Flux Map and Sedimentary Basins Map will Reduce the Risk of Exploration of Hydrocarbons
}

\author{
Surya Prakash Kapoor ${ }^{1}$, Aastha Kapoor ${ }^{2, *}$ \\ ${ }^{1}$ Department of Physics, Panjab University, India \\ ${ }^{2}$ Department of Biosciences and Bioengineering, Indian Institute of Technology Bombay, India
}

Copyright $\bigcirc 2016$ by authors, all rights reserved. Authors agree that this article remains permanently open access under the terms of the Creative Commons Attribution License 4.0 International License

\begin{abstract}
Temperature is the most sensitive parameter in hydrocarbon generation. None of the sediments will pass through the whole maturation process unless the initial geothermal gradient is greater than $33.7^{\circ} \mathrm{C} / \mathrm{km}$. Corresponding to this value of geothermal gradient the terrestrial heat flux value comes out to be $67.4 \mathrm{milli} \mathrm{W} / \mathrm{m}^{2} / \mathrm{s}$. Fortunately, the terrestrial heat flux map for India is readily available in the geothermal atlas of India (1991 edition). Simultaneously, the sedimentary basins map of India prepared by director general hydrocarbons, manifesting there in 26 sedimentary basins is also available. During exploration, so far only 13 sedimentary basins have yielded favorable results and the efforts in case of remaining 13 basins went futile. In order to solve this predicament of reducing the risk in exploration we have proposed to amalgamate both the maps to prepare a common map which will be far more useful and can be further extended to global scale.
\end{abstract}

Keywords Sedimentary Basins Map, Heat Flow Value Map, Exploration of Hydrocarbons

\section{Introduction}

Life on earth is nurtured as a consequence of two selfsustained energy sources: nuclear fission reactor in earth's core and fusion reactor in sun's core. The core of Earth dissipates more energy towards the surface and into space, than the net amount it receives from solar radiation. The combined effect of both solar and geothermal energies drive the atmospheric changes and oceans currents, thus allowing maintenance of an average surface temperature of $15^{\circ} \mathrm{C}$. All other conventional and non-conventional forms of energies like hydel energy, wind energy, nuclear energy and energy entrapped in fossil fuels is a manifestation of both geothermal and solar energies. Two primary types of fossil fuels on which much of the world economy rests are coal and hydrocarbons.

Petroleum exploration has been revolutionized over the last one and a half century, by use of non-invasive techniques for gathering sub-surface information to identify petroliferous sedimentary basins world over. Even though these techniques are no substitute for manual drilling, they are very useful for preliminary screening. While two of these non- invasive methods use gravity meters and magnetometers to measure variations in earth's gravitational pull or magnetic field to assess occurrence of dense hydrocarbon-laden source rocks, they have their share of anomalies and require highly skilled and experienced personnel to accurately interpret the data. These methods are fairly recent and have been introduced to supplement seismic data which was being limited by variations in elasticity of rocks and scattering of seismic signals due to presence of faults. Even though these latest methods are equipped to generate highly reliable data, most of the useful information is masked by noise generated by various factors like:

- Presence of electrical power lines and transformers which interferes with magnetometer readings on surface, probing into deeper sections which causes loss of instrument sensitivity.

- Buried water pipes and sub-surface variations can give rise to uncertainties in readings and mislead to modelling of identical final results in spite of dissimilar basin configurations.

Despite intensive private and national oil exploration initiatives, only $17 \%$ of total sedimentary area of India has been so far exploited for commercial production of petroleum. By and large remaining $\sim 80 \%$ is under various stages of exploration, which is likely to be completed in 3 years as proposed by Directorate General of Hydrocarbons, 
India in their recent report (2014) [1]. Increase in petroleum exploration efficiency has been gradual over last two decades.

\section{Hypothesis}

In our current study we have proposed an alternative approach for preliminary screening before petroleum exploration, which is based on the phenomenon of petroleum genesis, according to which basic components for petroleum formation are - organic rich rock, heat and pressure. Although the existence of pressure should not be discounted, in this article we focus on other two characteristics. We suggest the amalgamation of sedimentary basins map of India with the terrestrial heat flux map for improving the efficiency of initial screening.

\subsection{Petroliferous Sedimentary Basins and Heat Flow Regions}

Since the inception of first well at Digboi, Assam, India in 1889, Indian subcontinent has been extensively mapped for occurrence of petroliferous sedimentary rocks. Sedimentary basins are divided into 4 groups or categories based on the current petroleum generation prospectus (Fig.1 (A)). Category I basins are proven with commercial productivity and are presently being utilized for petroleum generation. Seven out of twenty six basins of the Indian subcontinent fall under category I, namely- Assam Shelf, Assam-Arakan Basin, Cambay Basin, Cauvery Basin, Krishna-Godavari Basin, Mumbai-Off Shore Basin and Rajasthan Basin. Category II basins are identified for their prospectus but not yet exploited, followed by category III and category IV basins which are prospective and potentially prospective respectively, as described in the DGH report prepared by Bhardwaj \& Saini in 2011 [2,3].

The current map of sedimentary basins of India is based on rock quality and organic richness. Both these attributes are measured by Rock-Eval pyrolysis and total organic carbon (TOC) which are widely used methods to characterize source rocks, first proposed by Tissot \& Welte and Peters, $[4,5]$.

Heat flow map of India was prepared by geological survey of India (GSI) in 1987 and updated in 1991 (Fig. 1(B)). Geothermal temperature gradient and heat flow data was collected by GSI from 340 natural "hot springs" spread over different parts of India, by digging shallow tube wells for various purposes. (Table 1). The temperatures of these springs vary from just over $5^{\circ} \mathrm{C}$ in excess of the mean ambient temperature $\left(15^{\circ} \mathrm{C}-30^{\circ} \mathrm{C}\right)$ of the area to the boiling point of water at the altitude of their respective occurrence. In course of systematic ground water studies of the country large tracts of hot ground water with $15^{\circ}-20^{\circ} \mathrm{C}$ excess temperatures over the mean ambient values have been recorded in different areas of country. High bottom hole temperatures $\left(140{ }^{\circ} \mathrm{C}-200{ }^{\circ} \mathrm{C}\right)$ have also been recorded in the drill holes in some of the sedimentary basins explored for hydrocarbon prospects. All these features are pointers to the presence of anomalous geothermal regimes in various domains. The heat flow values range between 30 and 468 $\mathrm{mw} / \mathrm{m}^{2}$ and have been grouped into five zones accordingly. The geothermal provinces in the country are characterized by (i) Tertiary and Quaternary orogenic activity in the Himalayas accompanied by recorded and dated Tertiary magmatism and metamorphic events; (ii) Mesozoic and Tertiary block faulting and epeirogenic activity in the shield areas with no apparent evidences of later Tertiary or younger magmatism; and (iii) moderately active seismicity and neotectonism. Preliminary estimates based on theoretical parameters suggest that from 113 systems identified so far, a total of $10,000 \mathrm{mw}$ power could be extracted from low to medium enthalpy fluids as proposed by Krishna Swami \& Ravi Shanker [6]. The figure is, however, theoretical and tentative. Terrestrial heat flux map of India shows regions of high heat flux in red with values $>180$ milli $\mathrm{W} / \mathrm{m}^{2} / \mathrm{s}$, followed by regions in green and blue with values $100-180 \mathrm{milli} \mathrm{W} / \mathrm{m}^{2} / \mathrm{s}$ and $70-100 \mathrm{milli}$ $\mathrm{W} / \mathrm{m}^{2} / \mathrm{s}$ respectively. 

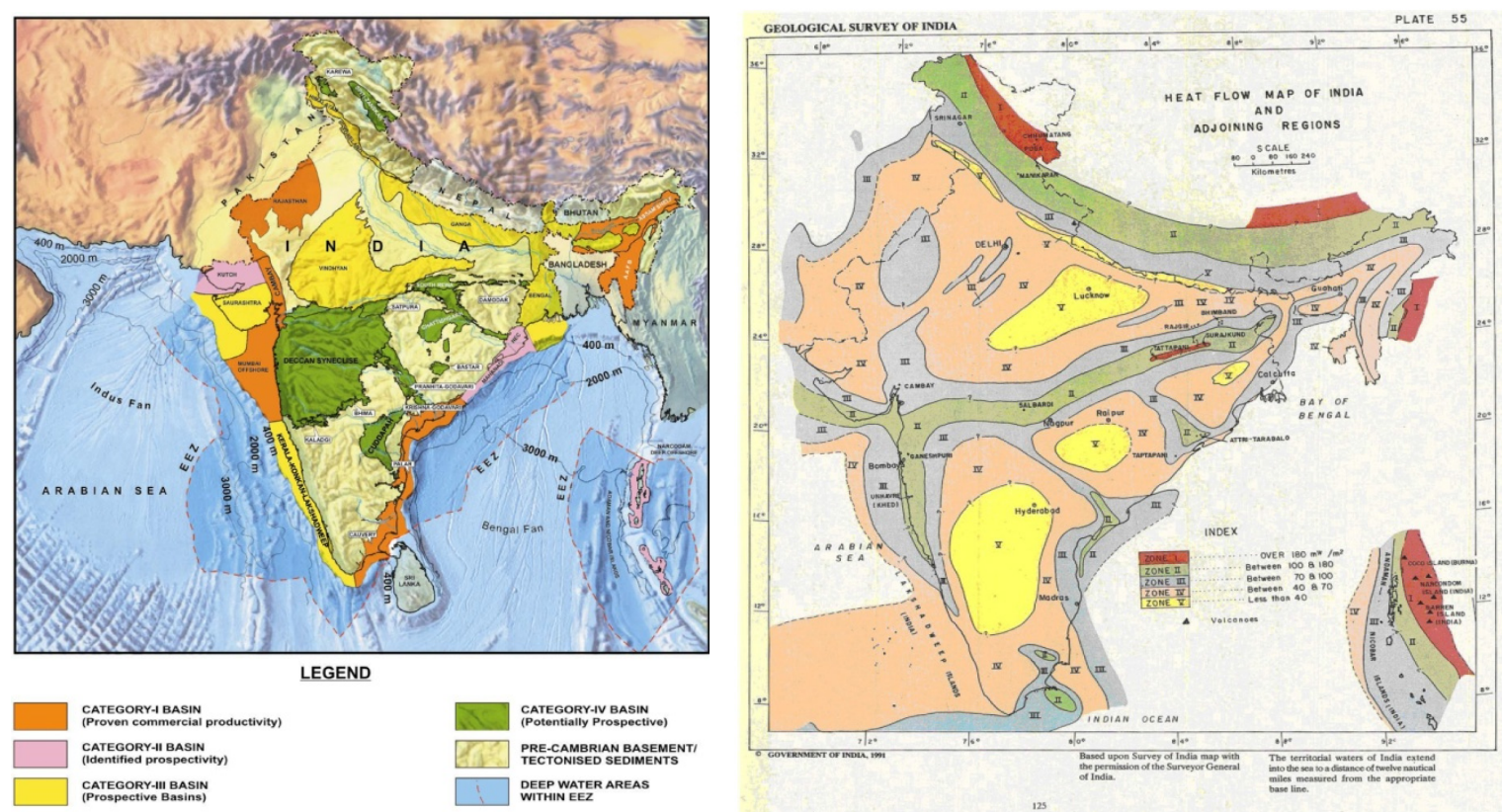

Figure 1. (A). Sedimentary Basins of India (Directorate General of Hydrocarbons, under Ministry of Petroleum \& Natural Gas, Govt. of India) (B). Heat Flow Map of India (GSI, 1987 \&1991).

\subsection{Correlation Analysis of Sediment Quality and Heat Flow}

We hypothesized that petroleum formation is a manifestation of geothermal energy which must be required to elevate sub-surface temperature gradient above $33.7^{\circ} \mathrm{C} / \mathrm{km}$ to cause thermal maturation of carbon substrate. In order to confirm this theory we used existing data on sediment quality from petroliferous sedimentary basins of India and showed that conversion of organic carbon to petroleum occurs in presence of high geothermal energy. Sediment quality was represented by total organic carbon (TOC) value which is a measure of amount of hydrocarbon (in $\mathrm{mg}$ ) present in one gram of rock. Geothermal energy was presented in terms of terrestrial heat flux values (in milli $\mathrm{W} / \mathrm{m}^{2} / \mathrm{s}$ ), since heat flow shows little correlation to crustal age, ocean depth at the sampling site, or the inferred thickness of the plate, it is nearly constant through the Atlantic and Indian ocean crust and Pacific ocean crust older than about 40 million years [7] and is a close indicator of earth's geothermal energy capacity (Table. 1). Petroleum generation potential was measured as total of $S_{1}$ and $S_{2}$ values which represent free hydrocarbon present in the rock and pyrolyzable hydrocarbon content respectively.

Existing data from seven locations (Fig. 2, Table. 2) within Cat I basin (South Cambay sub-basin, entire Mumbai-off shore basin, Barmer sub-basin under Rajasthan basin, Disang group under Assam-Arakan basin, UpperAssam shelf, Nagapattinam sub-basin under Cauvery basin and off-shore regions of Krishna-Godavari basin) was obtained from published literature and data in the public domain; and compared with respective heat flow values of the region. We found a positive correlation between occurrence of petroleum and heat flux values, suggesting that petroleum formation and complete maturation occurs in presence of geothermal energy, hence over-laying both the sedimentary basins map of India and heat flux map should identify regions of thermally mature sedimentary rocks which have higher hydrocarbon generation potential. 


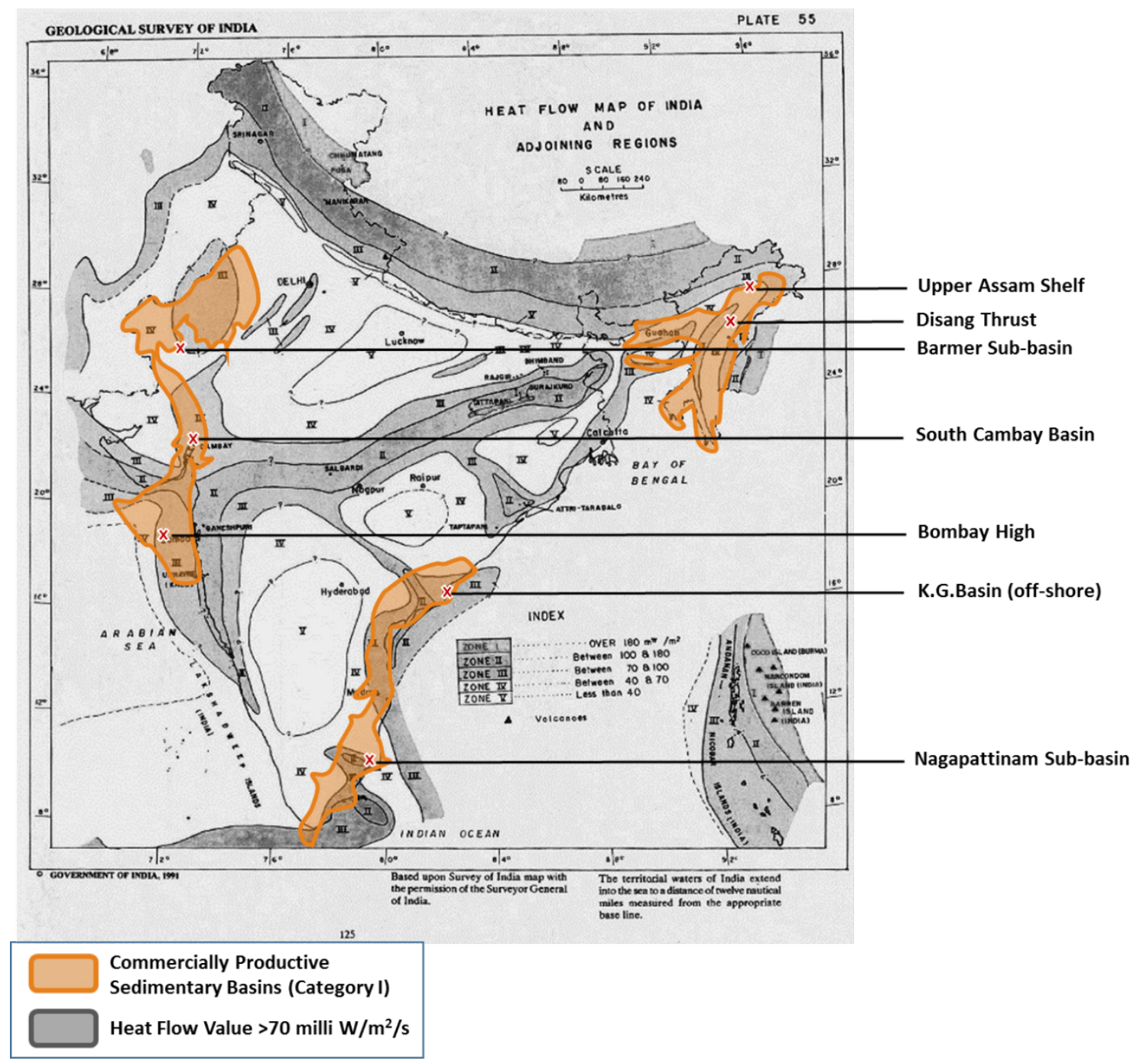

Figure 2. Overlay map showing regions with high probability of petroleum occurrence within petroliferous sedimentary basins of India corresponding to high heat flow value $\left(>70 \mathrm{milli} \mathrm{W} / \mathrm{m}^{2} / \mathrm{s}\right)$. Locations marked $(\mathrm{X})$ on the map represent sites with existing data on sediment quality, which were analyzed and compared with heat flow values of the region to understand correlation between both the parameters.

Interestingly, six of these sites and most other portions within petroliferous sedimentary basins of India overlapped with regions of high heat flux values $(>70$ milli $\mathrm{W} / \mathrm{m}^{2} / \mathrm{s}$ ), (Fig.2). High heat flux values are indicative of presence of high sub-surface temperatures, which are an essential for petroleum generation and existence. $33.7^{\circ} \mathrm{C} / \mathrm{km}$ is the basal temperature gradient needed for thermal conversion of kerogens into small molecular weight hydrocarbons and petroleum formation. Terrestrial heat flow value of $67.4 \mathrm{milli} \mathrm{W} / \mathrm{m}^{2} / \mathrm{s}$ corresponds to thermal gradient of $33.7^{\circ} \mathrm{C} / \mathrm{km}$ (Table. 1), as computed from index of geothermal characteristics of boreholes/springs data as documented in geothermal atlas of India [8]. Despite the occurrence of high quality organic sedimentary rocks in petroliferous basins, there are regions of discontinuity within them. For instance within Upper-Assam Shelf Basin, Disang thrust is an area with low potential for petroleum generation, which is also associated with occurrence of low heat flux values in the area (Table. 2). Therefore, in order to identify regions of thermally mature sedimentary rocks within category I and category II basins of India, overlay of both sedimentary map and terrestrial heat flow maps is essential. Even though sedimentary map successfully identifies regions of rich organic rocks, it does not warrant extraction of petroleum due to low thermal maturation and subsequently low hydrocarbon generation potential of the rock, thus supporting our hypothesis. 
Table 1. Index for Geothermal Characteristics of Thermal Springs/Bore Holes (GSI, 1987 \& 1991)

\begin{tabular}{|c|c|c|c|c|c|c|}
\hline $\begin{array}{l}\text { SURFACE } \\
\text { TEMP ('C) }\end{array}$ & $\begin{array}{l}\text { DISCHARGE } \\
\text { IN LPS * }\end{array}$ & $\begin{array}{c}\text { RESERVOIR } \\
\text { TEMP (C) } \\
\qquad \text { COMPUTED } \\
* * *\end{array}$ & $\begin{array}{l}\text { THERMAL } \\
\text { GRADIENT } \\
\text { (C } / \mathrm{Km})\end{array}$ & $\begin{array}{l}\text { HEAT } \\
\text { FLOW } \\
\left(\mathrm{mW} / \mathrm{M}^{2}\right) \\
* *\end{array}$ & $\begin{array}{l}\text { PROBABLE DEPTH OF } \\
\text { RESERVOIR (km) ON } \\
\text { COMPUTED BASE TEMP }\end{array}$ & $\begin{array}{l}\text { TYPE OF } \\
\text { WATER }\end{array}$ \\
\hline$\square<30$ & $\begin{array}{l}\triangle \text { FEEBLE } \\
\text { Not meosuro } \\
\text { ble }\end{array}$ & $0<30$ & 8 NORMAL & $\nabla$ ze 60 & ] NOT KNOWN & $\diamond \mathrm{NaCl}_{-}$ \\
\hline D $30-40$ & $\triangle$ LOW $_{\text {UptoILPS }}$ & $30-60$ & $8_{3307}^{30-45}$ & 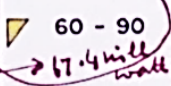 & $\angle 0.5$ & $\triangle \mathrm{CoMgHCO}_{3}$ \\
\hline D $41-60$ & $\triangle$ MODERATE & $60-90$ & $z^{45-60}$ & $\nabla 90-120$ & [ $0.5=1$ & $\diamond \mathrm{NaHCO}_{3}$ \\
\hline $61-80$ & $\triangle_{4-10 \text { LPS }}^{H I G H}$ & $090-120$ & $\nabla^{60-120}$ & $\nabla \quad 120-180$ & a $1-1.5$ & $\triangle \mathrm{COM}_{8} \mathrm{SO}_{4}$ \\
\hline$\square 81-90$ & $\begin{array}{l}\triangle \text { copIOUS } \\
\text { Over IOLPS }\end{array}$ & $120-150$ & $\nabla^{120-150}$ & $\nabla^{180-240}$ & ㄱ $1.5-2$ & $\varnothing$ MIXED L \\
\hline E. $91-100$ & & $O_{150-200}$ & $\nabla^{150-180}$ & $\nabla^{240-300}$ & [] $2-3$ & \\
\hline 回 BOILING & -2 & $0200 \ldots$ & $\gamma^{: 80+}$ & $\nabla 300+$ & Q $3+1$ & \\
\hline
\end{tabular}

Table 2. Co-occurrence of rich organic sediments and high heat-flow values in commercially productive petroliferous basins of Indian subcontinent

\begin{tabular}{llllll}
\hline S.L.No. & $\begin{array}{l}\text { Petroliferous basins } \\
\text { of India }\end{array}$ & Sub-basins & $\begin{array}{l}\mathrm{S}_{1}+\mathrm{S}_{2}^{*} \\
(\mathrm{mg} \mathrm{HC} / \mathrm{g} \mathrm{rock})\end{array}$ & $\begin{array}{l}\text { TOC* } \\
(\mathrm{wt} \%)\end{array}$ & $\begin{array}{l}\text { Heat Flow Value References** } \\
\left(\mathrm{milli} \mathrm{W} / \mathrm{m}^{2} / \mathrm{s}\right)\end{array}$
\end{tabular}

\begin{tabular}{|c|c|c|c|c|c|c|}
\hline & & & & & & \\
\hline 1 & Cambay basin & South Cambay & NA & $2.6 \%$ & 70-100 & [13.8] \\
\hline & & & & & $100-180$ & \\
\hline 2 & Mumbai offshore basin & - & $2.9-23.33$ & $2.03-8.8 \%$ & $70-100$ & [14.8] \\
\hline 3 & Rajasthan basin & Barmer sub-basin & NA & $0.5-4.5 \%$ & $70-100$ & {$[15.8]$} \\
\hline & & & & & & \\
\hline 4 & Assam-Arakan basin & Disang group & $0-0.3$ & $0.13-1.53$ & $40-70$ & [16.8] \\
\hline & & & & & $70-100$ & \\
\hline 5 & Assam shelf & Upper-Assam shelf & $5.2-7.2$ & $1.25-6$ & $70-100$ & [17.8] \\
\hline 6 & Cauvery basin & Nagapattinam sub basin & $3.5-22.44$ & $1.91-10.07$ & $70-100$ & [18.8] \\
\hline & & & (S2 only) & & & \\
\hline 7 & Krishna-Godavari basin & Off-shore region & $0.366-22.02$ & $0.18-3.33$ & $70-100$ & [19.8] \\
\hline
\end{tabular}

- Data available in public domain

- Literature referred to obtain parameter values

HC-Hydrocarbon, SI-Free HC,S2-HC obtained after thermal cracking. TOC-Total organic carbon, NA-Not available

\section{Discussion}

Petroleum exploration and detection have witnessed new advancements in technology, but the progress has been rather gradual over the last two decades. Techniques like hyper spectral remote sensing analysis have contributed significantly towards detection of petroliferous rocks, but, since most of these methods are empirical in approach, they are limited by their efficiency. In our study we propose a theoretical approach to supplement the current exploratory regime; which is based on correlation analysis of sedimentary rock quality and corresponding heat flow values essential for thermal maturation of the rocks. This study has been performed in the Indian context, nevertheless it explains the existence of a generalized phenomenon which can be further extended to a global scale. It will not only significantly increase the efficiency of petroleum exploration, but also save valuable resources and time by circumventing the practice of carpet bombing for hydrocarbon hunt.

Theory of petroleum genesis, has been divided into organic and inorganic formation, based on source of carbon involved in hydrocarbon generation [9]. Though both these processes are debatable with evidences favouring each; high 
temperature and high pressurete are essential pre-requisites in both cases. So one can argue that regions with high temperatures and corresponding high heat flow values ( $>67.4 \mathrm{milli} \mathrm{W} / \mathrm{m}^{2} / \mathrm{s}$ ) should be enriched in petroleum generation potential, irrespective of the petroleum formation mechanism. In case of organic formation, higher temperatures are essentially needed for 'catagenesis' step, in which high molecular weight kerogen is broken into smaller thermodynamically favoured hydrocarbons. This is a narrow thermal window which allows conversion of kerogen into oil, with higher temperatures leading to conversion to natural gas while lower temperatures leaving kerogens intact. In a special case of fast track maturation of organic hydrocarbons, regions of hydrothermal vents in deep oceans, were found to unusually high temperatures which assist in rapid thermal cracking of biogenic substrates. These vents have been identified along mid ocean ridge of east-Pacific rise and the mid-Atlantic-ridge, where tectonic activity has also been recorded with two tectonic plates diverging and forming new crust. Sea water descends from the flanks to depths of fissured rocks and emerge through vents at temperatures from 60 to $464^{\circ} \mathrm{C}$ as super critical fluid, which has properties of both gas and liquid. The significance of super critical conditions in terms of hydrothermal circulation, mineral deposit formation, geochemical fluxes, and biological activity is highly rewarding in fast track maturation of hydrocarbons [10]. Existence of chemo-autotropic bacteria around these vents and their role in supporting higher marine life (like giant worms and clamps), is evidential that during the process of petroleum formation and lithification in these vents, fossilized marine species were thriving on chemoautotrophic bacteria, which exclusively use chemical energy from sulphides $(\mathrm{H}, \mathrm{Cu}, \mathrm{Pb}, \mathrm{Zn}, \mathrm{Ag})$ to prepare food [11]. This method is also a classic case where geothermal energy alone fuels the synthesis of hydrocarbons, without the raw material being synthesized by solar energy.

Process of inorganic conversion of petroleum is relatively faster than organic process. In subduction zones like Indonesia's northern Bura basin high levels of geothermal energy leads to high heat flow values of $161 \mathrm{milli} \mathrm{W} / \mathrm{m}^{2} / \mathrm{s}$ contributing to rapid conversion of rocks of calcium carbonate to $\mathrm{CO}_{2}$ and $\mathrm{H}_{2} \mathrm{O}$ and subsequently to hydrocarbons. Consistent rapid production of petroleum by inorganic process has enabled Indonesia to produce 1 million barrels of crude oil daily along with record production of gas. Andaman Nicobar Islands in India being the northern extension of Indonesian subduction zone, should be a potential site for extraction of hydrocarbons as well. In regions of inorganic conversion, high temperature and high pressure leads to elevation of boiling points of hydrocarbons, thereby evading their volatilization and escape, unlike the organic conversion zones where high temperatures $\left(>470^{\circ} \mathrm{C}\right)$ may lead to over-maturation of oil and conversion to natural gas. While geothermal energy is needed for formation of petroleum through both organic and inorganic process, further investigation on existence of different qualities and varieties of generated hydrocarbons, needs to be done.

Based on the studies carried out in different parts of the globe, it is now considered that the presence of an active heat source (either cooling magmatic bodies in upper crust or evidences of Quaternary/ Recent volcanism) and / or presence of channels permitting up flow of geothermal fluids from deeper levels to the surface are generally responsible for the existence of surface geothermal manifestations. In India Cambay Graben Province is a glaring example of cooling magmatic body in the upper crust. Cambay geothermal area coincides with Cambay sedimentary basin which is one of the petroliferous basins of India, with North Cambay having higher petroleum production than South Cambay basin. Cambay graben geothermal province is $200 \mathrm{~km}$ long and $50 \mathrm{~km}$ wide down faulted area with late Tertiary reactivation, plutonism, and recent seismicity. This province also contains oil and gas deposits. Moderate temperature gradients $\left(40^{\circ} \pm 15^{\circ} \mathrm{C} / \mathrm{km}\right)$ and heat flow of $\left(75 \pm 18 \mathrm{milli} \mathrm{W} / \mathrm{m}^{2} / \mathrm{s}\right)$, and the high bottom hole temperature $\left(100^{\circ}\right.$ to $\left.145^{\circ} \mathrm{C}\right)$ have been recorded in the oil wells from the depth range of $1.7 \mathrm{~km}$ to $1.9 \mathrm{~km}$. Steam blow outs have been recorded in some of the oil wells from depths ranging between $1500 \mathrm{~m}$ to $3400 \mathrm{~m}$. In India there are no recorded evidences of recent magmatism except for a solitary instance of current volcanism in "Barren Island" in the Andaman Sea.

From our analysis, we speculate that regions of foothill regions of Himalayas bear potential of petroleum generation and yield due to high geothermal energy of the region. The formation of Himalayan Mountains is a manifestation of this geothermal energy, which led to continent-continent collision between Indian plate with the Asian and Burmese crustal plates in the north and east respectively. The collision took place during middle and late tertiary period with several phases of granitic activity, the youngest of which has been dated between 3 and 5 million years. Large number of thermal springs occur in this area, many of which of show boiling point temperatures at the elevation of their respective occurrences. The thermal activity is strongest adjacent to Indus- Tsungbo Suture Zone in the North West Himalayas which is considered to be plate margin. In the Himalayas, a phase of 3.5 million years old granitic episode has been identified at Chhumathang which seems to have continued upto Quaternary times along the Indus - Tsungbo Suture Zone. Chhumathang Granite is intruded by still younger (but undated) aplites pegmatites and quartz veins. Fumarolic sulphur deposits are seen at Puga. All this indicates that the magmatic activity continued upto fairly late Quaternary times in this sector of convergent plate boundary. Puga and Chhumathang areas are examples of this type of occurrence with temperature gradients in excess of $100^{\circ} \mathrm{C} / \mathrm{km}$ and heat flow in excess of 200 milli W/ $\mathrm{m}^{2} / \mathrm{s}$. Along the Indus- Tsangpo Suture, Pliocene magmatism is reported south of LHASA in the 
proximity of Yangbajain geothermal field in Tibet and lateQuaternary Volcanoes in Tenchong in Western Yunnan [6]. From the data analysis we presented above, we established that both abiogenic and biogenic hydrocarbons are formed as a result of geothermal energy and since high geothermal activity is observed adjacent to the Indus - Tsungbo and Indus Tsangpo Suture Zones, likelihood of organic rich sedimentary rocks is high here. This regions has also been placed in Category III basins of India, which have been deemed prospective for petroleum generation.

From the arguments presented here and previous reports, it is evident that geothermal energy is crucial in effecting tectonic movements [12] and petroleum generation, hence considering its relevance during petroleum exploration will yield fruitful results.

\section{Conclusions}

- Superior sediment quality (TOC $>0.5 \%)$ and high terrestrial heat-flow values ( $>67.4 \mathrm{milli} \mathrm{W} / \mathrm{m}^{2} / \mathrm{s}$ ) are essential for petroleum formation and its thermal maturation.

- Sedimentary rocks in regions of geothermal province have high petroleum generation potential $\left(\mathrm{S}_{1}+\mathrm{S}_{2}>3 \mathrm{mg} \mathrm{HC} / \mathrm{g}\right.$ rock $)$.

- By amalgamation of sedimentary basins map and heat-flow map of India regions of high petroleum generation potential identified - Andaman Nicobar Islands (Category II, sedimentary basin) and NorthWest Himalayas (Category III, sedimentary basin).

- Correlation studies carried out between sediment quality and geothermal energy can be further refined using modelling techniques and employed for preliminary petroleum exploration on a global scale.

\section{REFERENCES}

[1] Directorate General of Hydrocarbons (DGH), India. Petroleum exploration and production activity reports 2014 . Available from: www.dghindia.org

[2] Bhardwaj, V.K., Saini S. Hydrocarbon potential of India. Glimpses Geosci Res India. 2010;251-2.

[3] Directorate General of Hydrocarbons (DGH), India. Petroleum exploration and production activity reports [Internet]. 2011. Available from: www.dghindia.org

[4] Peters KE. Guidelines for evaluating petroleum source rocks using programmed pyrolysis. Bull AAPG. 1986;318-29.

[5] Tissot, B.P., Welte DH. Petroleum formation and occurrence. 2nd ed. Berlin: Springer-Verlag; 1984. 699 p.

[6] Swami, Krishna, Shankar R. Scope of development, exploration and preliminary assessment of the geothermal resources potential of India, Record Geological Survey of
India. 1982.

[7] Don A. Terrestrial heat flow: New theory of earth [Internet]. 2nd ed. Cambridge: Cambridge University Press; 2007. 333348 p. Available from: Cambridge Books Onlinehttp://dx.doi.org/10.1017/CBO9781139167291.031

[8] Geological Survey of India (GSI): Geothermal Atlas of India. $1987 \& 1991$.

[9] Laherrere. No free lunch part1: A critique of Thomas Gold's claims for abiotic oil. 2004. p. 10. Available from: http://www.fromthewilderness.com

[10] Cesare E. Planet Earth: Cosmology, geology and the evolution of life and environment. 1997;

[11] C S. Chemosynthesis on the deep seafloor. Oceanus. 1992;35:74-8.

[12] Kapoor SP, Chauhan BC. Earthquake and Geothermal Energy. 2013 Sep 30 [cited 2016 Feb 24];17. Available from: http://arxiv.org/abs/1309.7738

[13] Saxena SK, Saxena RK, Anand R, Singh H, Singh RR. Predicting the Temperature of Hydrocarbon Expulsion from Oil Asphaltene Kinetics and Oil Source Correlation: A Case Study of South Cambay Basin, India. AAPG Annual Convention. American Association of Petroleum Geologists (AAPG.). 2007.

[14] Goswami, Basant Giri, Harvir Singh, A.K. Bhatnagar, A.K.Sinha RRS. Petroleum Systems of the Mumbai Offshore Basin, India, by Basant Giri Goswami, Harvir Singh, Ashok Kumar Bhatnagar, Adarsh Kumar Sinha, And Ram Raj Singh, \#10154 (2007). AAPG Annual Convention. 2007 [cited 2016 Feb 7]. Available from: http://www.searchanddiscovery.com/documents/2007/07099 goswami/

[15] Farrimond P, Naidu BS, Burley SD, Dolson J, Whiteley N, Kothari V. Geochemical characterization of oils and their source rocks in the Barmer Basin, Rajasthan, India. Pet Geosci. 2015 Nov;21(4):301-21. Available from: http://pg.lyellcollection.org/lookup/doi/10.1144/petgeo2014075

[16] Gogoi BK, Sarmah RK. Evaluation of geochemical characteristics of shale of Disang Group in a part of AssamArakan basin in perspective of its hydrocarbon potential. Sci Vis. 2013;13(3):103-12.

[17] S.Pahrai, Harvir Singh, I.V.S.V.Prasad RRS. Petroleum Systems of Upper Assam Shelf, India. Geohorizons. 2008.

[18] Mala Janardhanan, Dr.B.G.Goswami JP. Petroleum Source Rock Evaluation of the Argillaceous Sediments in a part of Nagapattinam Sub basin, Cauvery Basin. Bienn Int Conf Expo. 2013.

[19] Ramachandran K, Babu V, Behera BK, Harinarayana T. Source rock analysis, thermal maturation and hydrocarbon generation using rock-eval pyrolysis in parts of KrishnaGodavari basin, India: a case study. J Pet Explor Prod Technol. 2012 Nov 4 [cited 2016 Feb 7];3(1):11-20. Available from: http://link.springer.com/10.1007/s13202012-0041-y 